\title{
OBITUARIES
}

\section{Professor David Oates, MA, FSA, FBA (1927-2004)}

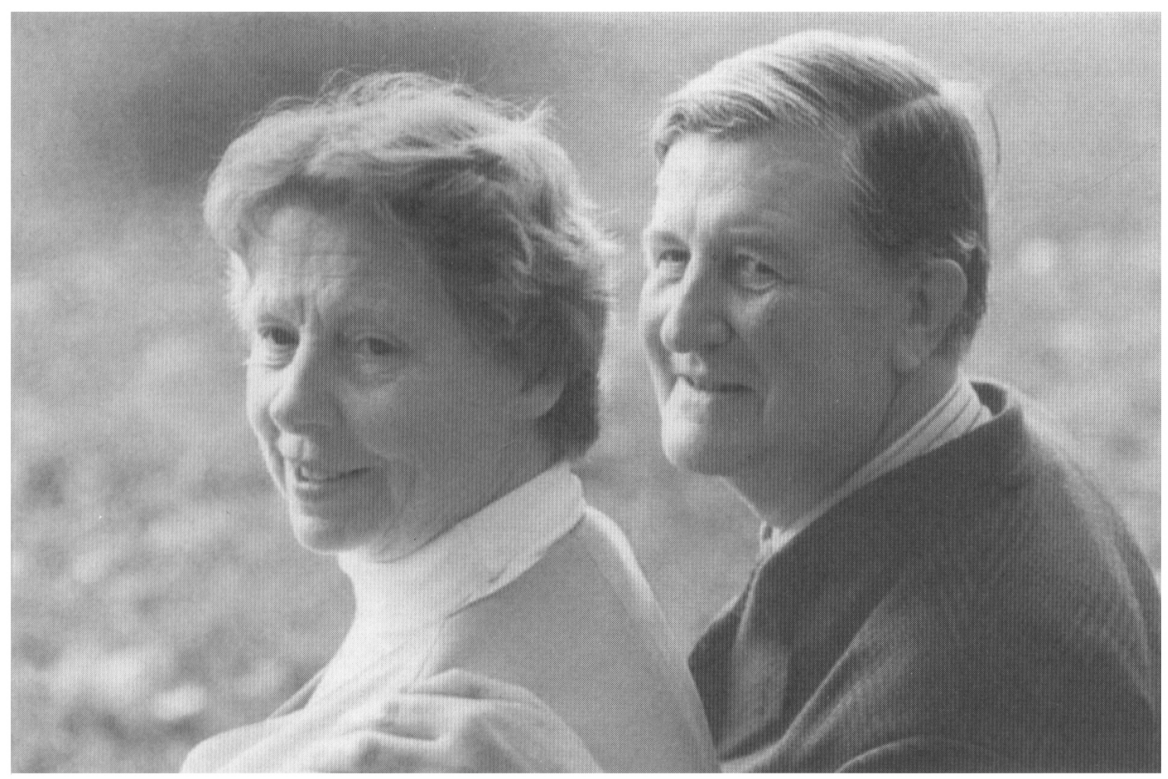

Joan and David Oates

It was with great sorrow that the School learnt of the death, in Cambridge, of David Oates, on 22 March 2004 at the age of 77. David served the School in many capacities for half a century. Between 1955 and 1971 he worked as an archaeologist on the School's excavations at Nimrud and Tell al-Rimah, both in northern Iraq, and served the School as its Assistant Director (from 1958), joint Director (from 1961) and Director resident in Baghdad (1965-69). He was on the Council of the School for many years, becoming Chairman in 1988, Vice-President in 1997, and President from 2000 until his death. In 1999 he became the third recipient (after Max Mallowan and Seton Lloyd) of the School's highest honour: the Gertrude Bell medal. On the occasion of his 75 th birthday in 2002 he was presented with a volume of papers entitled Of Pots and Plans, written by forty-one scholars from fourteen different countries and edited by six members of the School. It contains David's bibliography (pp. 399-401).

Edward Ernest David Michael Oates was born at Stoke Climsland in Cornwall on 25 February 1927. He was educated at Callington County School, Oundle School and at Trinity College, Cambridge, where he read classics and archaeology. As Rome Scholar in Classical Studies at the British School in Rome (1949-51) he took part in his first archaeological fieldwork in an Arab country, a survey of Roman and post-Roman settlement in Libya, which he wrote up as his dissertation when appointed to a Research Fellowship at Trinity in 1951. In 1953-4 he took part in the excavations at the palace of the Byzantine emperors in Istanbul. In 1954 he was elected a Fellow of the Society of Antiquaries of London, and in the same year the Stein-Arnold Committee of the British Academy sent him to northern Iraq to review the work of Sir Aurel Stein. This led, eventually, to a monograph: Studies in the Ancient History of Northern Iraq, published by the British Academy in 1968. It rapidly sold out, but we are happy to announce that it is being reprinted thanks to a generous grant in David's memory by The Charlotte Bonham-Carter Charitable Trust.

There was a reason for the delay in the original publication: in 1955 David was "poached" by Max Mallowan for work on the excavations at the Assyrian capital of Nimrud. During his first season David became adept in the complexities of excavating and interpreting mud-brick architecture and producing clear and accurate plans which became a feature of his publications. Mallowan 
said of him, "He is a master of mudbrick ... there is no better fieldworker in all Mesopotamia". David also met the American archaeologist, Joan Lines. He described her to his lifelong friend, Tom Faber, as having "terrific charm" and added "I think she is wonderful". They married in 1956, had three children, and formed a very successful archaeological partnership, cooperating in many publications of which, most appropriately, one of the last was Nimrud - An Assyrian Imperial City Revealed, published by the School in 2001, a masterful and eminently readable summary of all the work at the site carried out over more than a century-and-a-half. In 1958, David became field-director at Nimrud and moved the focus of the excavations from the citadel to the arsenal-palace, which became famous under the name Fort Shalmaneser. Here he made some spectacular finds including the carved throne-base of Shalmaneser III that is one of the treasures of the Iraq Museum; thankfully it remained undamaged when the Museum was looted in April 2003, but many of the ivories, which had been found in the storerooms of Fort Shalmaneser, were not so fortunate, some being stolen, while others, soaked in sewage and still lying virtually inaccessible in a bank-vault, may be beyond repair.

In 1964, David began excavations at a new site west of the Tigris near Tell Afar. This was Tell al-Rimah where a regional palace and archive of the 18 th century $\mathrm{BC}$ was discovered. A temple, built by Shamshi-Adad I around $1800 \mathrm{BC}$, continued in use, with some gaps and many rebuildings, throughout the second millennium and was replaced by a Neo-Assyrian shrine. David skilfully unravelled this sequence of mud-brick buildings, the earliest of which had a complex façade of mud-brick engaged columns with alternating twisted and palm-trunk decoration. Between 1957 and 1965, when he became Director of the School and took up residence with his family in Baghdad, David was a Fellow and Lecturer in Archaeology and Ancient History at Trinity. During the Six-Day War in 1967, the family remained in Baghdad, watched over by their many Iraqi friends. David was a good Arabic speaker and was on excellent terms with colleagues in Baghdad, local villagers and his workmen, who referred to him affectionately as Sheikh Daoud. However, after the Baath coup in 1968, the Oateses felt it was time to leave.

David, therefore, accepted the post of Professor of Western Asiatic Archaeology at the Institute of Archaeology, London University, where he taught from 1969, taking early retirement in 1982. In 1974 he was elected a Fellow of the illustrious British Academy. In 1976 he re-opened Max Mallowan's excavations at Tell Brak in north-eastern Syria, and he and Joan continued to work there for many years. Declining health obliged him to hand over the running of the excavations to younger colleagues although he remained director and he and Joan continued to visit the site regularly. They maintained close links with their Syrian and Iraqi colleagues, many of whom were good friends, and they regularly attended conferences in both countries, and elsewhere. David took great pleasure in the visits to London of Iraqi colleagues (funded in part by the School) for the Nimrud Conference in March 2002 and the 49e Rencontre Assyriologique Internationale in July 2003. The invasion of Iraq and looting of the museums in Baghdad and Mosul, where so much of the material he had excavated had been stored, caused him great grief.

Between 1997 and his death David was a Fellow of the McDonald Institute for Archaeological Research at Cambridge University and he continued to work on the final reports of the Brak excavations, three volumes of which have now appeared. As John Curtis stated in his obituary in the Independent (1 April 2004), "Both Nimrud and Tell al-Rimah were excavations in the grand style, employing up to several hundred workmen ... Much of the specialist work, such as tracing mud-brick walls ... and identifying archaeological deposits was done by ... Shergatis, so that young western supervisors had much less of a hands-on role than they do in modern excavations." The Brak excavations, however, employ all the latest techniques in surveying, excavation, recovery of objects through flotation, and conservation. The publication reports include specialist analysis of the faunal, archaeobotanical and micromorphological remains, which were ignored in earlier excavations. David was able to bridge the gap between the two styles of excavation and use the best of both.

At David's funeral in Trinity College Chapel on 31 March, his friend Tom Faber gave an address. They had been at school and Trinity together and, as he said, "once David made a friend the friendship lasted for life". Indeed, Tom Faber died not long after David. He described David's prowess as a sportsman ("he played fives with brutal efficiency and pretty good tennis too", to 
which he later added golf), his "prodigious gift for languages, ancient and modern" (the latter to include Italian, French, Arabic and Turkish), and his academic accomplishments. At school, for instance, "as a senior boy ... his party trick was to read the lesson at House Prayers in English, but from a Greek testament, without [the] housemaster detecting what he was up to", and "in later years [he] could astonish a party of modern Greeks by reciting in ancient Greek an ode on the death of Heracleitus". He quoted from some of David's letters. In one David wrote, in January 1951, of his experiences in Libya, "The short time I have spent in another atmosphere has shown me how much more I have to learn, and made me wonder whether the values of the academic world were not overrated ... I feel that I want to do something more directly useful than academic research." Thus David bridged another gap, that between academic research and practical field archaeology. He successfully passed on these skills to his students at the Institute of Archaeology and to generations of eager archaeologists.

D.C.

\section{Jeremy Black, MA, DPhil (1951-2004)}

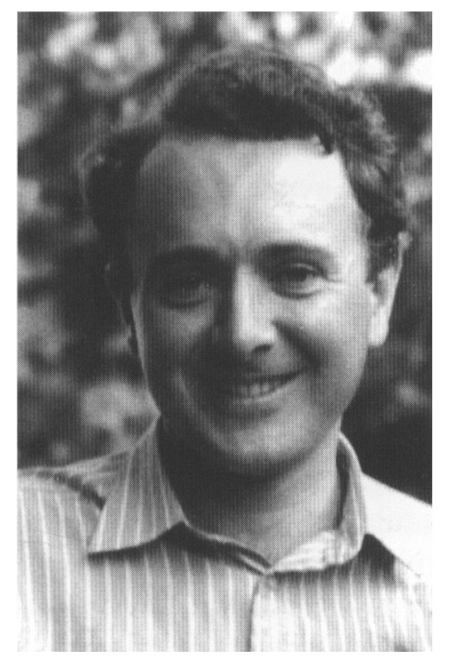

Dr Jeremy Black died unexpectedly in his sleep at home in Summertown, Oxford, on 28 April at the age of fifty-two. Jeremy was naturally companionable, a dear friend to a great number of people. The remarkably large congregation that packed St Andrews in Oxford for his funeral service in May was voluble testimony to the very great personal impact that his quiet and modest personality had on the intersecting worlds of Assyriology, the University of Oxford and music. His loss was felt internationally; that month a memorial service took place in Chicago. His life is already commemorated by the establishment of a new fund, the Jeremy Allen Black Trust for Assyriology. It is good also to learn that former graduate students plan a volume of essays to honour the memory of a gifted linguist, teacher and scholar.

Jeremy Allen Black was born in Middlesex and grew up in Berkshire, where he received his early education. While reading Classics as an Exhibitioner at Oxford he fell under the spell of languages and cultures of ancient Iraq, and after gaining his BA took a BPhil in Cuneiform Studies in 1975. His bachelor's thesis was entitled "A History of Nippur, from the Earliest Times to the End of the Kassite Period", demonstrating already a preoccupation with Sumer and Sumerian that became the hallmark of his academic career. The thesis was much cited in the more recent study of Nippur by Steven W. Cole, Nippur in Late Assyrian Times (1996), who described it as the "only systematic treatment of Nippur's early history to date". Despite this, it was never published. Jeremy's postgraduate research, guided by O. R. Gurney, his teacher at Oxford, and 